\title{
PENGEMBANGAN MEDIA VIDEO ANIMASI UNTUK MENINGKATKAN MOTIVASI BELAJAR DAN KARAKTER KERJA KERAS SISWA SEKOLAH DASAR
}

\author{
Umi Wuryanti dan Badrun Kartowagiran \\ Program Pascasarjana Universitas Negeri Yogyakarta \\ email: mi_wur197@yahoo.com
}

\begin{abstract}
A bstrak: Penelitian ini bertujuan (1) menghasilkan media pembelajaran; dan (2) mendeskripsikan efektivitas media video animasi untuk meningkatkan motivasi belajar dan karakter kerja keras siswa kelas V SD Gugus Sodo Kecamatan Paliyan. Penelitian dan pengembangan ini mengacu pada sepuluh langkah yang dikembangkan Borg \& Gall. Desain pengembangan dilakukan dari langkah pertama sampai kesembilan, yaitu: (1) studi pendahuluan; (2) perencanaan; (3) pengembangan produk awal; (4) uji coba awal; (5) revisi produk awal; (6) uji coba lapangan; (7) revisi produk hasil uji coba lapangan; (8) uji coba lapangan operasional; dan (9) revisi produk akhir. Uji coba produk menggunakan teknik quasi experiment untuk menguji produk yang dikembangkannya. Keefektifan media video animasi untuk meningkatkan motivasi belajar dan karakter kerja keras siswa diketahui dengan menggunakan uji t. Efektivitas dilihat dari rata-rata skor motivasi belajar dan karakter kerja keras pada kelas eksperimen dan kelas kontrol. Terdapat perbedaan signifikan skor motivasi belajar dan karakter kerja keras siswa antara sebelumdan sesudah menggunakan media video animasi dalam pembelajaran.
\end{abstract}

Kata Kunci: media video animasi, motivasi belajar, karakter kerja keras

\section{DEVELOPING ANIMATION VIDEO MEDIA TO IMPROVE LEARNING MOTIVATION AND CHARACTER HARD WORK ON THE FIFTH GRADE STUDENTS OFELEMENTARY SCHOOL}

\begin{abstract}
A bstract: This study aims to (1) produce; and (2) determine the effectiveness of animations video media to improve learning motivation and character the hard work on the fifth grade students of Elementary School Gugus Sodo District Paliyan. Research and development refers to the 10 steps developed by Borg \& Gall. The design of development was carried from the first step until the ninth, namely: (1) a preliminary study; (2) planning; (3) development of initial product; (4) the initial trials; (5) the revision of the initial product; (6) field trials; ( 7) revision of the results of a field trial products; (8) operational field trials; and (9) the revision of the final product. Product trial using quasi experiment tecnique to examine the product that has developed. For knowing the effectivity of animation video to enhanced learning motivation and hard work character using $t$ test. The effectiveness seen from the average score of learning motivation and character of hard work on the experimental class and control class. A ny difference of significance of learning motivation and hard work scores of students between the characters before and after using animed video media in learning.
\end{abstract}

Keywords: animation video media, motivation to learn, hard working character

\section{PENDAHULUAN}

Pendidikan merupakan implementasi untuk mencerdaskan kehidupan bangsa. Hubungan antara konsepsi upaya mencerdaskan bangsa dan implementasinya dapat dilakukan dengan beberapa cara, antara lain pengembangan kurikulum, penyiapan guru melalui preservice education, pendidik- an dan pelatihan guru dalam inservice training, sistem pembinaan tenaga kependidikan dalam on the job training, proses pembelajaran khususnya dalam pemilihan strategi pembelajaran, dan pelaksanaan penilaian pendidikan.

Keberhasilan proses pembelajaran dipengaruhi oleh beberapa aspek, antara lain 
penggunaan strategi dalam pembelajaran di kelas. Peran guru dalam proses pembelajaran bukan satu-satunya sumber dan pusat dari pembelajaran (Oya\& Budiningsi h, 2014: 117). Kemampuan guru memilih strategi untuk pembelajarannya dalam upaya untuk meningkatkan ketercapaian tujuan belajar yang merujuk pada prestasi siswa di kelas. Kombartzsky, et al. (2010:426) menyatakan, " $V$ arious deep strategies have been designed and evaluated in order to improve students' learning from texts". Berbagai strategi dirancang dan dievaluasi untuk meningkatkan belajar siswa dari teks. Keterampilan seorang pendidik dalam mengembangkan media pembelajaran dengan memahami konsep dan aplikasi media dalam pembelajaran secara komprehensif.

Motivasi memegang peranan penting dalam proses belajar siswa. Menurut Orm$\operatorname{rod}(2009: 58-59)$, motivasi dapat meningkatkan prakarsa (inisiasi) dan kegigihan terhadap berbagai aktivitas. Siswa akan cenderung memulai sesuatu tugas yang diinginkan. Siswa juga akan cenderung melakukan tugas yang diinginkan itu sampai ia mampu menyelesaikannya. Tugas-tugas yang diperoleh siswamerupakanjembatan yang digunakan guru dalam proses pembelajaran sehingga siswa mampu untuk sampai pada tujuan belajarnya.

Selain pemilihan strategi pembelajaran yang tepat, ada faktor yang memegang peranan penting dalam keberhasilan proses belajar siswa, yaitu motivasi siswa dalam belajar. Elliott et al (2000: 332) menyatakan, "M otivation is defined as an internal state hat arouses us to action, pushes us in particular directions, and keeps us engaged in certain activities." Motivasi didefinisikan sebagai keadaan internal yang membangkitkan untuk bertindak, mendorong ke arah tertentu, dan melibatkan dalam kegiatan tertentu.
Proses pembelajaran memegang peranan yang sangat penting pada proses belajar siswa untuk mencapai tujuan belajar. Berdasarkan Permendikbud Nomor 65 Tahun 2013 Bab I tentang Standar Proses Pendidikan Dasar dan Menengah, bahwa proses pembelajaran pada satuan pendidikan diselenggarakan secara interaktif, inspiratif, menyenangkan, menantang, memotivasi siswauntuk berpartisipasi aktif, dan memberi ruang yang cukup bagi prakarsa, kreativitas, dan kemandirian sesuai dengan bakat, minat, dan perkembangan fisik serta psikologis siswa. Dornyei (2001:116) menyampaikan, "With motivation being as important a factor in learning success as argued earlier, teacher skills in motivating learners should be seen as central to teaching effectiveness". Dengan motivasi yang sama pentingnya faktor dalam keberhasilan belajar yang telah disepakati sebelumnya, keterampilan guru dalam memotivasi pelajar harus dilihat sebagai pusat pengajaran efektivitas.

Keberhasilan suatu pembelajaran tentu tidak hanya pada tercapainyatujuan pembelajaran pada aspek kognitif saja, akan tetapi dengan munculnya perilaku siswa yang berkarakter. Kondisi psikologis ditunjukkan melalui perilaku seseorang yang memiliki karakter. Siswa yang berkarakter sangatlah penting karena karakter merupakan perilaku moral yang akan membentuk manusia pada masa yang akan datang. Senada dengan yang disampaikan Lickona (2013:72), karakter terdiri atas nilai-nilai operatif, nilai-nilai yang berfungsi dalam praktik. Karakter tersebut tumbuh menjadi budi pekerti, sebuah batin yang diandalkan dan digunakan untuk merespons berbagai situasi dengan cara bermoral. Karakter akan terbentuk dan melekat pada diri sampai usia dewasa.

Karakter sebagai watak moral merupakan pengembangan dan perpaduan an- 
tara nilai-nilai dan sikap dalam bertindak. Woolfolk (2009:144-145) menyatakan bahwa penalaran moral adalah proses berpikir yang terlibat dalam sebuah pertimbangan tentangpertanyaan benar dan salah. Selanjutnya Woolfolk menjelaskan bahwa dalam prosespenalaran moral (moral reasoning) melibatkan pikiran tentang benar dan salah serta konstruksi aktif pertimbangan moral (moral judgement) melalui pertimbangan moral dalam pemahaman tentang aturan/ norma yang berlaku. Pendidikan karakter siswa tidak hanya cukup mengetahuibenarsalah dan baik-buruk, akan tetapi dengan berperilaku, bersikap dan bertindak berdasarkan nilai-nilai yang menjadi kepribadiannya.

Perjuangan para pahlawan memberikan pengetahuan kepada siswa bahwa dalam mencapai suatu keberhasilan maka dibutuhkan motivasi yangtinggi dan kerja keras untuk memperolehnya. Semangat, motivasi, dan kerja keras dalam memperjuangkan kemerdekaan Indonesia merupakan nilai yang dapat dijadikan inspirasi dan contoh nyata bagi siswa. Hal ini didukung dengan penelitian Patty, et. al. (2010:354) bahwa sebuah nilai dapat berfungsi untuk pedoman hidup yang mempengaruhi pengambilan keputusan dan memberikan dasar dalam menyusun tujuan yang bermakna.

Berdasarkan hasil studi pendahuluan melalui need analysis berupa observasi dan wawancara pada bulan Juni 2015 terlihat bahwa motivasi siswa untuk belajar IPS masih rendah yang dibuktikan dengan nilai ulangan harian siswa pada materi "Perjuangan Mempersiapkan Kemerdekaan Indonesia" sebanyak 66\% di bawah Kriteria Ketuntasan Minimal (KKM) sekolah, menurutguru kelas 5 ketika pembelajaran berlangsung banyak siswa yang kurang semangat untuk memperhatikan penjelasan terhadap materi tersebut. Selain itu, saat pem- belajaran IPS, guru hanya menggunakan mediagambar dan terbatas pada buku teks. Gambar tersebut berwarna hitam putih sehingga terlihat kurang menarik.

Hasil wawancara yang dilakukan menyebutkan bahwa kegiatan pembiasaan dalam rangka pembentukan karakter telah dilaksanakan. Namun, hasil yang dirasakan masih sangat kurang bagi siswa. Berdasarkan kondisi yang telah dipaparkan, maka penting untuk dilakukan sebuah inovasi pembelajaran. Robertson (2015:30) menegaskan, "Teachers also need professional development in the pedagogical application of those skills to improve teaching and learning. Technology support for teachers on a day-to-day basis is important as well". Guru juga perlu pengembangan profesional dalam aplikasi pedagogis keterampilan untuk meningkatkan pengajaran dan pembelajaran. Dukungan teknologi untuk guru sehari-hari juga penting. Kemampuan guru diharapkan untuk lebihterampil dan memberikan fasilitas dalam mendukung pembelajaran. Dengan pertimbangan efektivitas media pembelajaran yang dalamhal ini tujuan pembelajaran serta untuk meningkatkan motivasi dan karakter kerja keras siswa, karakteristik siswa, menyikapi keterbatasan sarana berupakomputer yang dimiliki oleh setiap sekolah, serta mempertimbangkan minat siswa terhadap media pembelajaran yang pernah digunakan sebelumnya oleh guru, maka penelitian ini dilakukan untuk mengembangkan media pembelajaran berupa video animasi untuk meningkatkan motivasi belajar serta karakter kerja keras siswa.

Pengondisian tempat belajar yang memungkinkan siswa memperoleh pengetahuannya perlu dilakukan untuk mencapai tujuan belajar. Menurut Newby, et al. (2000: 117), "A $n$ instructional medium as a means of providing a stimulus-rich environment for learning". Media instruksional merupakan sara- 
na yang memberikan lingkungan yang kaya stimulus untuk belajar sehingga siswa berada pada tempat yang nyaman untuk mendapatkan pengetahuannya. Hal tersebut sesuai langkah pengembangan media yang disampaikan Allesi \& Trollip (2001: 410), salah satu diantaranya yaitu planning (perencanaan), yang meliputi menentukan ruang lingkup materi, mengidentifikasi karakteristik siswa, merumuskan tujuan dan biaya, menghasilkan dokumen perencanaan, menghasilkan panduan gaya, menentukan dan mengumpulkan sumber, melakukan curah pendapat awal/ konsultasi kepada ahli, dan mendefinisikan tampilan dan nuansa.

Penelitian ini dibatasi pada masalah rendahnya motivasi belajar siswa, karakter kerja keras yang belum terlihat pada diri siswa, belum maksimalnya pemanfaatan media pembelajaran, dan kebutuhan guru akan media video animasi. Dengan demikian, penelitian ini difokuskan pada pengembangan media video animasi pada materi "Persiapan Kemerdekaan Indonesia"yang dirancang sebagai salah satu upayauntuk meningkatkan motivasi belajar dan karakter kerja keras siswa.

Jeong (2012:6) menegaskan:

"Among a variety of instructional media, video technology is believed to be particularly useful and suitable for problem-based learning because it can convey setting, characters, and action in an interesting way and can portray complex and interconnected problems".

Maksudnya, bahwa di antara berbagai mediapembelajaran, teknologi video diyakini sangat bergunadan cocok untuk pembelajaran berbasismasalah karenadapat menyampaikan pengaturan, karakter, dan tindakan dalamcara yang menarik dan dapat menggambarkan kompleks dan saling berhubungan dengan masalah. Selain itu, animasi juga efektif dalam hal pengembangan video animasi karena terbukti bahwa penggunaan film animasi berpengaruh dalam suatu pembelajaran (Astuti \& Mustadi, 2014).

Sementara itu, Dimerman (2009:910) menyatakan, "A science teacher may stress the perseverance of those students who have worked hard to improve". Seorang guru sains dapat menekankan ketekunan dari para siswa yang telah bekerja keras untuk peningkatan. Kerja keras dapat dibentuk melalui latihan ketekunan untuk mencapai tujuan belajarnya. Melalui video animasi yang dikembangkan dalam penelitian ini diharapkan mampu memberikan pengalaman belajar baru bagi siswa serta membantu guru dalam proses pembelajaran. Pengalaman belajar yang baru ini diharapkan membantu siswa agar termotivasi dalam belajar. Karakter-karakter dalam video animasi diharapkan mampu menanamkan nilai tentang bagaimana cara memperoleh sesuatu yang salah satunya dengan usaha keras.

\section{METODE}

Penelirian ini menggunakan model penelitian dan pengembangan yang dikembangkan Borg \& Gall (1983:775-776) yang terdiri atas sepuluh langkah tahapan. Desain penelitian ini dilaksanakan sampai pada tahap kesembilan, yaitu: (1) penelitian pendahuluan dan pengumpulan informasi; (2) perencanaan; (3) pengembangan draf produk; (4) uji coba terbatas; (5) merevisi hasil uji coba terbatas; (6) uji coba lapangan; (7) penyempurnaan produk hasil uji coba lapangan; (8) uji coba lapangan operasional; dan (9) penyempurnaan produk akhir.

Uji coba produk terdiri atas tiga tahap yaitu uji coba terbatas, uji coba lapangan, danuji coba lapangan operasional. Sebelum uji coba, produk perangkat pembelajaran divalidasi oleh ahli materi dan ahli media 
kemudian direvisi. Subjek uji coba dalam penelitian ini adalah siswa kelas V SD Gugus Sodo yang terdiri atas 6 orang siswa untuk uji coba terbatas, 8 orang siswa untuk uji coba diperluas, keduanya berasal dari SD Pelemgede Subjek uji coba lapangan ope rasional adalah 46 siswa yang terdiri atas 10 siswa kelas V SD Giring dan 10 siswa SD Paliyan III sebagai kelas kontrol dan 26 siswa kelas V SD Sodo sebagai kelas eksperimen yang memiliki karakteristik yang sama. Semua SD tersebut berada di wilayah $\mathrm{Ka}$ bupaten Gunungkidul.

Pengumpulan data dalam penelitian ini menggunakan teknik angket dan observasi. Instrumen pengumpulan data yang digunakan dalam penelitian ini adalah skala penilaian produk, skala motivasi belajar, angket penilaian diri tentang karakter kerja keras, pedoman observasi karakter, skala respons guru dan respons siswa.

Teknik analisis data yang digunakan dalam penelitian ini adalah analisis uji kelayakan produk dan analisis uji keefektifan produk media video animasi. Penilaian hasil uji kelayakan produk oleh ahli media dan ahli materi dikatakan memenuhi kriteria jika skor minimal yang dicapai $70 \%$ dengan kategori baik. Uji keefektifan produk dilakukan menggunakan uji t dan membandingkan rata-rata total skor hasil penilaian.

\section{HASIL DAN PEMBAHASAN Studi Pendahuluan}

Mediavideo animasi materi "Persiapan Kemerdekaan Indonesia" ini dikembangkan berdasarakan kebutuhan di lapangan akan suatau media sebagai alternatif sumber belajar yang mampu memberikan daya tarik kepada siswa untuk belajar dan membantu mempermudah siswa untuk memahami materi yang diajarkan. Pengumpulan informasi dilakukan melalui wawancara, observasi, dan analisis produk/ dokumen yang sudah ada.

Berdasarkan hasil wawancara yang dilakukan di sekolah wilayah Gugus Sodo, diketahui bahwa motivasi belajar siswa masih rendah, indikasinya di antaranya nilai Ulangan Harian IPSsiswasebanyak 66\%masih di bawah KKM. Menurut guru kelas 5 ketika pembelajaran berlangsung banyak siswa yang kurang semangat untuk memperhatikan penjelasan terhadap materi tersebut. Selain itu, saat pembelajaran IPS, guru hanya menggunakan media gambar dan terbatas pada buku teks. Gambar tersebut berwarnahitam putih sehingga terlihat kurang menarik.

Guru sebatas menggunakan buku paket yang ada dan terkadang hanya menggunakan media gambar dokumentasi. Hal ini diungkapkan oleh subjek sebagai berikut.

“Metode yang saya gunakan dalam pembelajaran IPS lebih banyak dengan metode ceramah, terkadang dalam pembelajaran saya selingi dengan penekanan gambar-gambar yang ada di buku paket yang dipegang siswa. Untuk penunjang pencapaian materi IPS lebih banyak sebatasmenggunakan buku paket yang ada (Wawancara dengan DY, bulan Juni 2015)."

Subjek yang sudah memiliki kualifikasi sarjana dengan kompetensi sejarah, sebenarnyasangat membantu dalam kegiatan pembelajaran. Di samping itu, di setiap sekolah juga terdapatfasilitas berupa LCD (Liquid C rytasl D isplay) yang dimungkinkan dapat membantu dalam kegiatan pembelajaran. Pengadaan LCD tersebut diadakan oleh pihak UPT dengan tujuan untuk dapat memenuhi pelayanan minimal di sekolah-sekolah. Hal ini diungkapkan oleh subjek dalam pernyataannya sebagai berikut.

"Sekolah terdapat banyak fasilitas di antaranya LCD dan internet. Jika dalam pembelajaran dibutuhkan referensi tambahan saya mencari referensi dari internet. Sebenarnya jika ada video atau film 
yang dapat digunakan dalam pembelajaran materi IPS akan lebih bagus dan menarik tentunya. (Wawancara dengan DY, bulan Juni 2015)."

Dalampemahaman terhadap nilai karakter yang ditanamkan dalam pelaksanaan pembelajaran, guru mengutarakan pentingnya membangun nilai karakter pada diri siswa. Hal ini diutarakan dalam pernyataan sebagai berikut.

“Pembelajaran mengenai karakter harus dilakukan dengan pembiasaan dan contoh-contoh modeling dalam pembentukan sikap yang baik. Sebenarnya pembelajaran tidak hanya menekankan pada aspek pengetahuan saja, akan tetapi aspek sikap atau karakter serta aspek keterampilan juga. Terlebih anak-anak sangat suka menonton TV yang sedikit banyak mempergaruhi perilaku anak-anak. Oleh karena itu, penanaman budaya berkarakter sangat diperlukan agar siswa terbangun jiwa yang pandai dan berkarakter (Wawancara dengan DY, Bulan Juni 2015)."

Pada tahap studi pustaka, peneliti me lakukan kajian teori-teori yang berkenaan dengan video animasi sebagai media untuk meningkatkan motivasi belajar dan karakter, terutama karakter kerja keras. Kajian tersebut dilakukan dengan menganalisis buku dan jurnal yang berkaitan dengan kebutuhan peneliti untuk mengembangkan media video animasi. Berdasarkan hasil studi pustaka yang telah dilakukan, diperoleh bahwa pembelajaran dengan menggunakan media video animasi mampu menarik siswa untuk belajar sehingga motivasi belajar siswa juga meningkat. Selain itu, materi IPS mengenai “Persiapan Kemerdekaan Indonesia" berisi materi ajar yang mengembangkan nilai-nilai karakter kerja keras pada diri siswa sehingga dilakukanlah penelitian untuk mengembangkan media video animasi.

Tahap analisis media dan dokumen yang digunakan diketahui bahwa siswa kurang antusias untuk belajar dengan gambar diam seperti dalam buku teks yang digunakan siswa. Hal tersebut mengindikasikan bahwa guru membutuhkan media pembelajaran yang dapat membangkitkan motivasi belajar siswa dan menumbuhkan karakter kerja keras. Mengingat di sekolah mempunyai sarana berupa Liquid Crytasl D isplay (LCD) proyektor dan laptop yang terbatas yang dipakai oleh guru, maka media yang dibutuhkan berupa media video animasi yang ditayangkan secara klasikal guna meningkatkan motivasi belajar dan karakter kerja keras siswa.

Berdasarkan hasil studi pendahuluan di atas dapatdisimpulkan bahwaguru membutuhkan media pembelajaran yang mampu memotivasi siswa dan memudahkan siswa dalam memahami materi ajar. Selain itu, media yang dibutuhkan guru juga harus memuat penanaman nilai karakter kerja keras supaya siswa meneladani sikap kerja keras dan mengembangkan karakter tersebut dalam mencapai tujuan belajar. Di samping itu, media video animasi ini juga disesuaikan dengan karakteristik siswa.

\section{Data Hasil Validasi A hli}

Data hasil penilaian kelayakan produk media video animasi oleh ahli materi mendapatskor total 65 dengan kategori "Sangat Baik". Ahli media memberikan penilaian dengan skor 74 dengan kategori juga "Sangat Baik". Sesuai penilaian tersebut, produk media video animasi yang dikembangkan dari aspek media dinyatakan layak untuk digunakan.

\section{A nalisis D ata H asil Uji Coba Terbatas}

Uji coba terbatas dilakukan pada 6 orang siswa kelas V SD Pelemgede. $\mathrm{Ke}$ enam siswa dipilih secara acak dengan memperhatikan kemampuan siswa, yaitu berkemampuantinggi, sedang, dan rendah. Uji coba terbatas ini dilakukan untuk me- 
ngumpulkan informasi sebagai bahan kajian perbaikan produk media video animasi dan memperoleh gambaran pembelajaran siswa di kelas. Data yang diperoleh berupa data respons siswa dan data respons guru.

\section{Respons Siswa}

Data hasil angket respons siswa terhadap penggunaan media video animasi yang dapat dilihat pada tabel 1 .

Tabel 1. Hasil Respons Siswa tentang ProdukM edia Video A nimasi

\begin{tabular}{ccccc} 
No. & Nama & $\begin{array}{c}\text { Total } \\
\text { Skor }\end{array}$ & Nilai & Kriteria \\
\hline 1. & DEF & 33 & B & Baik \\
2. & MA & 34 & A & Sangat Baik \\
3. & YD & 32 & B & Baik \\
4. & ADS & 34 & A & Sangat Baik \\
5. & UFW & 33 & B & Baik \\
6. & AS & 33 & B & Baik \\
Jumlah & 199 & & \\
\multicolumn{2}{r}{ Rata-rata } & 33,17 & B & Sangat Baik \\
\hline
\end{tabular}

Hasil respons siswa pada tabel di atas dapat disimpulkan bahwa rata-rata skor total responssiswa pada uji coba terbatas adalah 33,17 dengan kategori "Baik". Dengan demikian, pada uji coba terbatas ini siswa memberikan respons yang baik terhadap penggunaan media video animasi pada pembelajaran. Persentase respons siswa dapat dilihat pada Gambar 1.

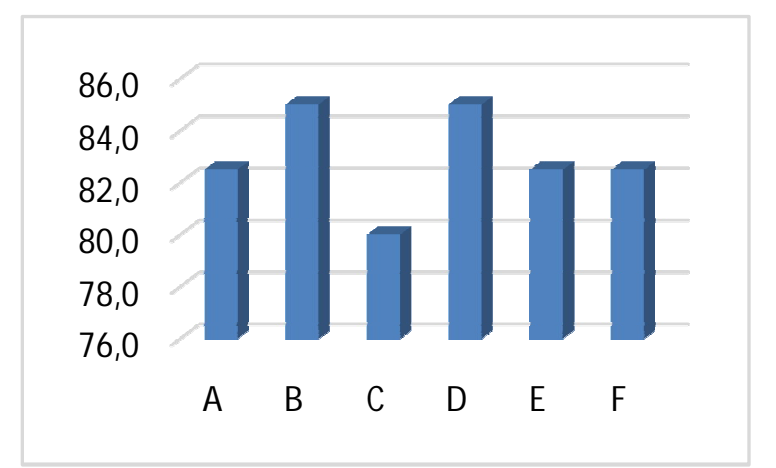
G ambar 1. Persentase Respons Siswa
pada Uji Coba Terbatas

\section{Respon G uru}

Data hasil dari angket respons guru terhadap keterlaksanaan penggunaan media video animasi dapat dilihat pada Tabel 2.

Tabel 2. Hasil Respons G uru tentang Produk M edia Video Animasi

\begin{tabular}{|c|c|c|c|}
\hline No. A spek & Skor & Nilai & Kategori \\
\hline 1. Pembelajaran & 7 & SB & Sangat Baik \\
\hline 2. Materi & 16 & B & Baik \\
\hline 3. Media & 9 & B & Baik \\
\hline Total Skor & 32 & B & Baik \\
\hline
\end{tabular}

Berdasarkan Tabel 2, responsguru terhadap keterlaksanaan dengan media video animasi pada proses pembelajaran sudah baik. Kategori "Baik" diperoleh dari total skor kedua aspek dengan persentase 80,83\%. Persentase respons guru terhadap keterlaksanaan media video animasi dalam pembelajaran di kelas dapat dilihat pada gambar berikut.

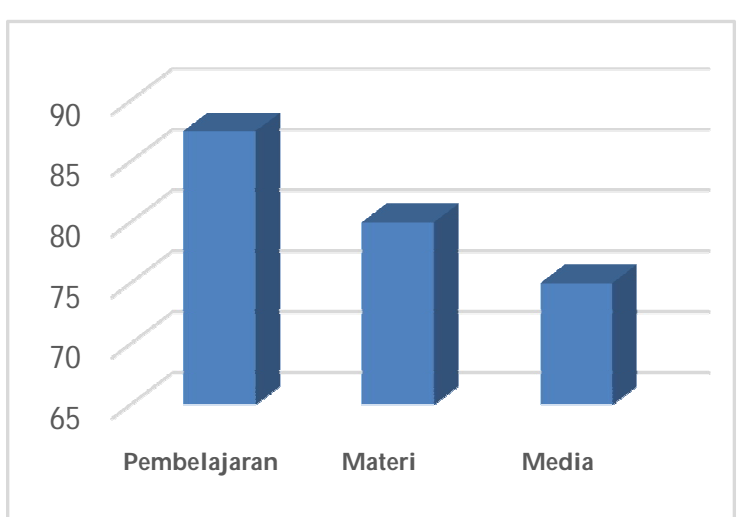

\section{G ambar 2. Persentase Skor Respons G uru pada Uji Coba Terbatas}

\section{Analisis D ata H asil Uji Coba Diperluas}

Uji coba diperluas dilakukan pada 8 orang siswa kelas V SD Pelemgede. Kedelapan siswa tersebut diambil secara acak dengan mempertimbangkan kemampuan rendah, sedang, dan tinggi. Data pada uji coba diperluas meliputi respons siswa dan respons guru. Berikut analisis masing-masing data. 


\section{Respon Siswa}

Data hasil angket respons siswa dapat dilihat pada Tabel 3.

Tabel 3. Hasil Respon Siswa tentang Produk pada Uji Coba Diperluas

\begin{tabular}{ccccc}
\hline No. & Nama & Total Skor & Nilai & Kriteria \\
\hline 1. & HNN & 40 & A & Sangat Baik \\
2. & GAD & 40 & A & Sangat Baik \\
3. & AOD & 40 & A & Sangat Baik \\
4. & FES & 38 & A & Sangat Baik \\
5. & BK & 37 & A & Sangat Baik \\
6. & DLA & 36 & A & Sangat Baik \\
7. & BWN & 36 & A & Sangat Baik \\
8. & AEF & 35 & A & Sangat Baik \\
\hline \multicolumn{2}{r}{ Jumlah } & 302 & & \\
Rata-rata & 37,75 & A & Sangat Baik \\
\hline
\end{tabular}

Berdasarkan data pada tabel di atas, dapat dilihat bahwa rata-rata respons siswa terhadap penggunaan media video animasi pada kategori "Sangat Baik". Sebanyak 8 siswa dari subjek uji coba diperluas memberikan penilaian dengan kategori "Sangat Baik" terhadap media video animasi dengan nilai $A$. Rata-rata keseluruhan respons subjek coba diperluas adalah 37,75 dengan kategori "Sangat Baik ". Persentase skor respons siswa pada uji coba diperluas yang dapat dilihat pada Gambar 3.

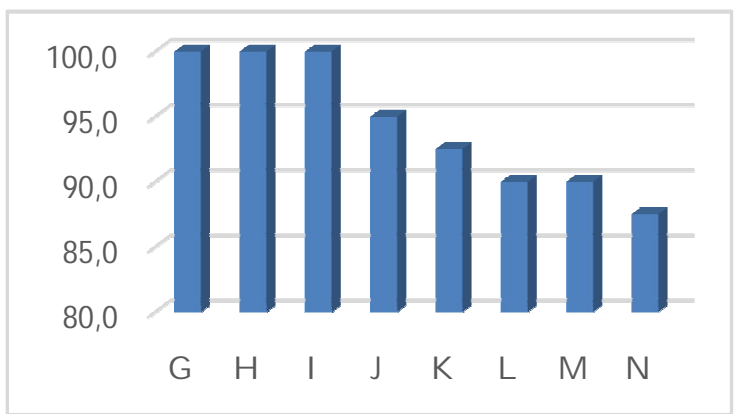

G ambar 3. Persentase Respons Siswa pada Uji Coba Diperluas

\section{Respon G uru}

Data hasil angket respons guru dapat dilihat pada Tabel 4 berikut.
Tabel 4. Hasil Respons Guru pada Uji Coba Diperluas

\begin{tabular}{llccc}
\hline No. & Aspek & Skor & Nilai & Kategori \\
\hline 1. & Pembelajaran & 8 & A & Sangat Baik \\
2. & Materi & 17 & A & Sangat Baik \\
3. & Media & 10 & B & Baik \\
\hline Total Skor & 35 & A & Sangat Baik \\
\hline
\end{tabular}

Berdasarkan tabel di atas, tahap uji coba diperluas ini respons guru terhadap penggunaan media video animasi dalam pembelajaran pada kategori "Sangat Baik". Aspek pembelajaran pada kategori "Sangat Baik", aspek materi pada kategori "Sangat Baik", sedangkan aspek media pada kategori "Baik". Persentase skor persentase respons guru terhadap produk media video animasi pada uji coba diperluas dapat dilihat pada Gambar 4.

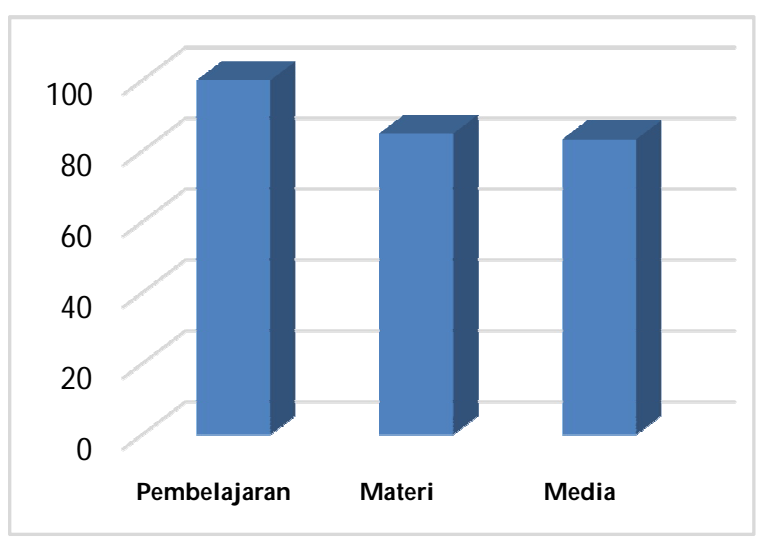

\section{G ambar 4. Persentase Skor Respons G uru pada Uji Coba Diperluas}

\section{A nalisisD ata Hasil Uji Coba O perasional \\ Uji coba ini melibatkan dua kelas da- lam tiga sekolah. Dua kelas di satu sekolah sebagai kelas eksperimen dan duakelas di dua sekolah sebagai kelas kontrol.Sekolah yang digunakan sebagai eksperimen adalah SD Sodo dengan 26 siswa.Sedang sekolah yang digunakan sebagai kelas kontrol ada- lah SD Giring dengan 10 siswa dan SD Pa- liyan III dengan 10 siswa. Pada tahap uji coba operasional data yang berupa motiva- si belajar, hasil belajar kognitif, respons}


guru dan respons siswa dikumpulkan. Hasil analisis data untuk motivasi belajar dan karkater kerja keras siswa pada kegiatan uji cobaoperasional untuk kelas eksperimen menunjukkan adanya peningkatan hasil yang signifikan. Hal tersebut terlihat dari perbedaan peningkatan rata-rata total skor yang diperoleh seperti pada Tabel 5.

Tabel 5. Perbedaan Rata-Rata Total Skor Motivasi Belajar dan Karakter Kerja Keras

\begin{tabular}{lcccc}
\hline Data & Pre & Kriteria & Post & Kriteria \\
\hline Motivasi Belajar & 57,65 & B & 61,70 & A \\
$\begin{array}{l}\text { Karakter Kerja } \\
\text { Keras }\end{array}$ & 55,14 & C & 67,38 & B \\
\hline
\end{tabular}

Selainitu, berdasarkan hasil uji-t yang dilakukan di kelas ekperimen diperoleh nilai signifikansipada Tabel 6.

Tabel 6. Siginifikansi Uji t Kelas Eksperimen

\begin{tabular}{cc}
\hline Data & Signifikansi \\
\hline Motivasi Belajar & 0,000 \\
Karakter Kerja Keras & 0,000 \\
\hline
\end{tabular}

Berdasarkan tabel di atas, diperoleh nilai signifikansi untuk motivasi belajar dan karakter kerja keras sebebar 0,000. Artinya, ada perbedaan yang signifikan terhadap motivasi belajar dan karakter kerja kerassiswaantarasebelum menggunakan media video animasi dengan sesudah menggunakan media video animasi. Jadi, produk media video animasi yang dikembangkan efektif untuk meningkatkan motivasi belajar dan karakter kerja keras siswa kelas v SD.

\section{Respons Guru dan Siswa}

Respons guru setelah menggunakan media video animasi dengan memberi nilai penilaian guru adalah "Sangat Baik". Hasil tersebut dapat dilihat dari perolehan nilai yang diberikan, yaitu pada aspek materi memperoleh skor 23dengan nilai A kategori "Sangat Baik", pada aspek media memperoleh skor 21 dengan nilai A kategori "Sangat Baik". Berdasarkan angket respons dari 23 siswa memperoleh rata-rata skor sebesar 39,4 dengan kategori "Baik". Ini berarti bahwa 94\% respons siswa terhadap media video animasi sudah baik penggunaannya dalam kegiatan pembelajaran.

\section{Kajian Produk Akhir}

Produk akhir dalam penelitian ini merupakan hasil perbaikan dari saran dan masukan pada draf awal, uji coba terbatas, uji coba diperluas, dan uji coba operasional. Produk akhir dalam penelitian pengembangan ini berupa media video animasi dengan materi persiapan kemerdekaan Indonesia untuk siswa kelas 5 sekolah dasar.

Media video animasi dirancang dengan mempertimbangkan banyak hal, di antaranya materi, biaya, dan waktu. Materi yang dipilih sesuai kompetensi dasar dengan mempertimbangkan materi yang tidak mungkin untuk dihadirkan kembali karena berkaitan dengan sejarah. Biaya me nyesuaikan dengan dana peneliti untukmemungkinkan membuat video animasi dengan durasi yang menyesuaikan. Waktu yang dipertimbangkan yaitu materi yang ada di semester dua dan proses penyelesaian pembuatan video dilakukan sebelum materi itu tersampaikan sesuai program mengajar guru.

Desain dari media video animasi memiliki grafis background yang jelas, warna yangmeraik, gambar-gambar, animasi, musik, teks bacaan dan audio yang mendukung proses pembelajaran sehingga siswa termotivasi dan tertarik selama proses pembelajaran berlangsung. Media video animasi dilengkapi ringkasan dan soal evaluasi di setiap episode sehingga dapat dijadikan 
alat bantu untuk mengukur pemahaman siswa terhadap materi yang dipelajari. Me dia video animasi ini dilengkapi dengan dialog singkat yang menghubungkan dengan materi yang hendak dipelajari sehinggamenumbuhkan rasa ingin tahu siswa dalam memahami materi yang disampaikan. Media video animasi mampu meningkatkan motivasi belajar dan mengembangkan karakter kerja keras siswa melalui pemodelan karakter tokoh pada video.

\section{Pembahasan}

Penelitian ini mengembangkan me dia video animasi materi "Persiapan Kemerdekaan Indonesia" untuk siswa kelas V SD. Berdasarkan penilaian dari ahli materi produk media video animasi mendapat nilai sebesar 65 dengan kategori "Sangat Baik", sedangkan menurut ahli media, produk media video animasi ini mendapatkan nilai sebesar 74 kategori "Sangat Baik". Dari hasil penilaian ahli tersebut dapat disimpulkan bahwa media video animasi materi “Persiapan Kemerdekaan Indonesia" layak digunakan dalam penelitian ini.

Berdasarkan penilaian dari ahli materi, media video animasi ini dinilai sesuai kompetensi pembelajaran, sesuai tujuan pembelajaran, materi sesuai dengan kompetensi dasar, sesuai karakteristik siswa SD, konsep yang benar, disajikan dengan bahasayang sesuai. M enurut penilaian dari ahli media, media video animasi ini dinilai memiliki teks yang dapat terbaca, narasi sebagai penjelas, audio yang terdengar jernih, visual yang terlihat jelas, serta sound effect yang mendukung proses pembelajaran. Selain itu, media video animasi dapat diputar dengan mudah sehingga siswa terlihat senang dan tertarik dalam proses pembelajaran. Media video animasi ini membantu guru dalam menyampaikan materi kepada siswa dan memotivasi siswa dalam belajar yang baik sehingga menarik perhatian siswa saat pembelajaran di kelas.

Media video animasi dengan materi “Persiapan Kemerdekaan Indonesia” me muat contoh karakter kerja keras yang mana siswa dapat belajar untuk tekun dan bekerjakerasmelakukan sesuatu dalam pencapaian yang mejadi tujuannya. Pencapaian tersebutmembutuhkan perjuangan dan kerja keras seperti yang tersiratkan dalam video animasi materi "Persiapan Kemerdekaan Indonesia" untuk memperoleh kemerdekaan. Para pejuang memeperlihatkan kegigihannya dan pantang menyerah dalam memperebut kemerdekaan Indonesia dari penjajah. Contoh dari pemodelan tersebut mengonstruksikan pengetahuan yang telah dimiliki siswa untuk melakukan hal yang sama dalam belajaranya. Siswa dapat melihat adegan-adegan yang diperlihatkan dalam media video animasi tersebut yang diperankan oleh tokoh-tokoh pejuang. Contoh-contoh karakter yang dimodelkan oleh tokoh-tokoh dalam video animasi disajikan dengan jelas dan sesuai dengan kondisi siswa yang sering dialami di sekolah.

Motivasi tidak dapat dilihat secara fisik bahwa daya itu ada dalam diri siswa. Motivasi berkaitan dengan tujuan yang memberikan daya atau penggerak bagi suatu tindakan. Motivasi juga berhubungan dengan aktivitas fisik seseorang, yang mencakup usaha, kegigihan, dan tindakan lain yang bisa diamati secara berkelanjutan. Di samping itu, aktivitas mental di antaranya perencanaan, penghafalan, pengorganisasian, pemonitoran, pengambilan keputusan, penyelesaian masalah, dan peniIaian kemajuan. Bland (2012:98), menyatakan, "When the two elements were combined into a video that incorporated audience reaction scenes and content interaction via computer responses, the students were significantly motivated to view the lesson". Ketika dua elemen 
digabungkan menjadi sebuah video yang dimasukkan penonton adegan reaksi dan interaksi konten melalui komputer, secara signifikan siswa termotivasi untuk melihat pelajaran. Oleh karena itu, siswa SD tergerak untuk memperhatikan materi ajar dalam proses pembelajaran.

Slavin (2009:334-336) menyebutkan cara yang dapat dilakukan guru untuk meningkatkan motivasi instrinsik yang salah satunya dengan menggunakan berbagai cara penyajian yang menarik. Penyajian yang menarik dalam proses pembelajaran dengan menggunakan bahan dan cara yang bermacam-macam dapat meningkatkan motivasi siswa untuk memperhatikannya. Seperti penelitian Tosti, Stephen, dan Gwo (2014:352) bahwa salah satu cara me ningkatkan motivasi belajar siswa dengan menerapkan pendekatan yang tepat. Dengan demikian, dengan penggunaan komputer, benda-benda konkret, atau melalui permainan atau simulasimotivasi belajar siswa dapat meningkat.

Materi "Persiapan Kemerdekaan Indonesia" dan contoh karakter yang dimodelkan dikemas dalam narasi dengan adegan-adegan seperti film yang berdurasi pendek, mampu menarik perhatian siswa dan menjadikan siswa tekun dalam belajarnya. Antusiasme siswa dalam proses pembelajaran dengan menggunakan media video animasi tersebut dari awal sampai akhir pembeljaran mengindikasikan bahwa motivasi belajar dan karakter kerja keras siswa meningkat.

Kajian dari produk media video animasi ini diperoleh berdasarkan hasil validasi oleh ahli materi dan ahli media, sehingga media video animasi ini layak digunakan dalam pembelajaran. Kajian yang menunjukkan adanya motivasi dan karakter yang meningkat diperoleh berdasarkan hasil analisis skala motivasi belajar siswa dan penilain diri siswa tentang karakter kerja keras. Selain itu, kajian terkait karakter kerja keras diperoleh berdasarkan analisis hasil pengamatan dengan menggunakan lembar observasi karakter kerja keras.

Berdasarkan hasil uji coba operasional yang dilakukan pada kelas $\mathrm{V}$ sebagai kelaseksperimen, media video animasi materi "Persiapan Kemerdekaan Indonesia" dinilai mampu meningkatkan motivasi belajar dan karakter kerja keras siswa kelas V SD Gugus Sodo. Hal tersebut didasarkan pada teori pemodelan yang dikemukakan oleh Bandura (1985:51) bahwa transformasi informasi dalam prosesnya dapat memberikan pengaruh terhadap perilaku seseorang karena mengandung atensi, retensi, produksi, dan motivasi yang pada akhirnya akan memberikan efek inhibisi/ disinhibisi kepada seseorang terhadap perilaku yang dipelajari. Melalui model tokoh-tokoh yang ada dalam media video animasi tersebut perilaku siswa dapat terpengaruh untuk mencontoh perilaku model. Pada produk media video animasi terdapat tokoh-tokoh yang memerankan model di setiap adeganadegan yang terbukti dapat meningkatkan karakter kerja keras siswa.

Merebaknya perkelahian dan tawuran antarpelajar, korupsi yang merajalela, serta kekerasan terhadap perempuan dan anak merupakan bukti adanya penurunan karakter. A rum \& Dressler (2002:608) mengungkapkan, "Children and particularly adolescents struggle often in interaction with school authority to define themselves as individuals with distinct identities. Identity formation involves challenges in many social psychological domains, including moral development". A nakanak dan khususnya remaja sering dalam interaksi dengan kewenangan sekolah untuk mendefinisikan diri mereka sebagai individu dengan identitas yang berbeda. Pembentukan identitas melibatkan tan- 
tangan pada psikologi sosial, termasuk perkembangan moral.

Strickland (2001:110) menyatakan, "Qualities of an individual's motivation are shaped during all stages of childhood". Kualitas ini dari individu motivasi berbentuk selama tahap masa kecil. Pembiasaan dan contoh yang ditanamkan di masa kecil akan membentuk kualitas individu di masa be rikutnya. Senada dengan pendapat di atas, Weissbourd, Scherer, \& Alexandria (2009: 231) menyatakan," $P$ arents and teachers together are powerful vehicles for driving the moral growth of adults and students". Orang tua dan guru bersama-sama merupakan kendaraan yang kuat untuk mendorong pertumbuhan moral orang dewasa dan siswa. Jelas bahwa orang tua dan guru mempunyai peranan yang kuat untuk pertumbuhan moral anak.

Teori pemodelan tersebut didukung pula teori pengkodean ganda yang dikemukakan oleh Paivio (2006:3), yakni bahwa informasi yang diterima siswa dalam bentuk visual dan dikombinasikan dengan informasi dalam bentuk visual yang dikemas dalam media pembelajaran dapat menunjang memori dan pemahaman siswa terhadap materi sehingga pembelajaran menjadi lebih efektif. Fungsi media video animasi telah berhasil memberikan fungsi psikologis yang mampu memotivasi siswa. $\mathrm{Hal}$ tersebut dapa dilihat dari peningkatan rata-rata skor motivasi belajar siswa antara sebelum dan sesudah menggunakan media video animasi.

Penyajian pembelajaran yang menarik dan melibatkan siswa dalam fantasi serta situasi tiruan (karakter fiktif) merupakan hal yang mendasari dalam pengembangan media video animasi. Video animasi yang didalamnya terdapat fantasi menggambarkan berbagai situasi tiruan sehingga siswa menjadi tertarik. Kim, et al. (2007:260) me- nyatakan, "A nimations might be more attractive and motivating". A nimasi mungkin akan lebih menarik dan memotivasi.Dari berbagai kajian dan penelitian yang sudah dilakukan dengan menggunakan media video animasi, didapatkan hasil bahwa penggunaan media video animasi materi “Persiapan Kemerdekaan Indonesia" dapat meningkatkan motivasi belajar siswa dan karakter kerja keras siswa kelas V SD Gugus Sodo Kecamatan Paliyan.

\section{PENUTUP}

Berdasarkan hasil dari penelitian pengembangan ini dapat ditarik simpulan sebagai berikut. Pertama, produk media video animasi pada materi "Persiapan Kemerdekaan Indonesia" dinyatakan layak oleh ahli materi dan ahli media untuk digunakan dengan kategori "Sangat Baik". Kedua, produk media video animasi pada materi "Persiapan Kemerdekaan Indonesia" efektif digunakan untuk meningkatkan motivasi belajar dan karakter kerja keras siswa kelas V Gugus Sodo, Kecamatan Paliyan berdasarkan hasil penelitian.

Pengembangan media video animasi untuk meningkatkan motivasi belajar dan karakter kerja keras siswa kelas V SD sudah diuji kelayakan dan keefektifannya. Oleh Karena itu, disarankan kepada guru untuk menggunakan media video animasi sebagai alternatif media dalam pembelajaran dan media video animasi yang sejenis dapat dikembangkan lebih lanjut untuk materi yang berbeda.

\section{UCAPAN TERIMA KASIH}

Dengan mengucap Alhamdulillah penulis memanjatkan puji dan syukur ke hadirat Allah Swt. atas terselesaikannya tulisan ini. Dalam kesempatan ini penulis ingin mengucapkan terima kasih yang sebesarbesarnya kepada semua pihak yang telah 
membantu dalam penelitian hingga selesainya tulisan ini. Ucapan terima kasih terutama disampaikan kepada para anggota De wan Redaksi Jurnal Pendidikan Karakter yang telah menerima dan memproses tulisan ini hingga layak dimuat pada edisi ini dengan harapan dan doa semoga semua pihak yang telah membantu akan mendapatkan balasan dari Allah Swt.

\section{DAFTAR PUSTAKA}

Alessi, S.M., \& Trollip, S.R. 2001. M ultimedia for Learning: $M$ ethode and $D$ evelopment. Massachusetts: A Pearson Education Company.

Arum, R. \& Dressler, J. 2002. “Education and Crime". Ensyclopedia of Crime and Justice (2th ed). Vol. 2, pp. 607-613.

Astuti, Y., \& Mustadi, A. 2014. “Pengaruh Penggunaan M edia Film A nimasi terhadapKeterampilan Menulis Karangan Narasi Siswa Kelas V SD". Jurnal Prima Edukasia, Vol. 2, No. 2, hlm. 250-262.

Bandura, A. 1985. Social Foundation of Thought \& Action: A Social Cognitive Theory. New Jersey: Prentice Hall, Inc.

Bland R.B. 2012. "Impact of Video Presentation Featureson Instructional Achievement and Intrinsic Motivaton in Secondary School Learners". Disertasi, University ff North Texas, 2012. Dissertation Publishing UMI Number 3573828.

Borg, W. R. \& Gall, M. D. 1983. Educational Reasearch. N ew York: Longman Inc.
Dimerman, S. 2009. Character is the Key: $\mathrm{H}$ ow to $\mathrm{U}$ nlock the Best in out Children and O urselves. Ontario: RK Studio.

Dornyei, Z. 2001. Teaching and Researching M otivation. England: Pearson Education.

Elliott, S.N., et al. 2000. Educational Psychology: Effective Teaching, Effective Learning (3th ed). Singapore: McGraw-Hill.

Jeong, C.H. 2012. “The Effect of Using Three Types of Instrustional Media on Comprehension and Motivation of Korean College Students in an Online Course". Disertasi, University of Nevada, 2012. Dissertation Publishing UMI Number 3511816.

Kim S., et al. 2007. "The Effect of A nimation on Comprehension and Interest. Journal of Computer Assisted Learning,Vol. 23, Issue 3, pp. 260-270.

Kombartzsky U., et al. 2010. “Developing and Evaluating Strategy for Learning from Animations". Learning and Instruction, Vol. 20, Issue 5, pp. 424-433.

Lickona, T. 2013. Educating for Character. Terjemahan Lita S. Bandung: Nusa Media.

Newby, et al. 2000. Instructional Technology for Teaching and Learning. New Jersey: Prentice Hall.

Ormrod, J. E. 2009. Educational Psycology D eveloping,Jilid 1 (6th ed). (Terjemahan Penerbit Erlangga). Jakarta: Gelora A ksara Pratama. 
Oya, R.N., \& Budiningsih, C.A. 2014. “Pe ningkatan Motivasi Belajar dan Hasil Belajar Bahasa Indonesia Menggunakan Model Pemeblajaran Kreatif dan Produktif". Jurnal Prima Edukasia, Vol. 2, No. 1,hlm.116-126.

Paivio, A. 2006. Dual Coding Theory and Education. Diakses Tanggal 5 Agustus 2015 dari www.umich.edu/ rdytol$\mathrm{rn} /$ pathwaysconference/ presentatio ns/ paivio.pdf.

Patty, F., et al. 2010. M otivation and Commitment to Social $V$ alues: The Roles of A ge and Gender. Vol. 34, pp. 354-362.

Peraturan Menteri Pendidikan dan Kebudayaan RI Nomor 65 Tahun 2013, tentang Standar Proses Pendidikan Dasar dan Menengah.

Robertson, W. 2015. "Technology and Student Motivation to Learn". Disertasi, Concordia University Chicago, 2015. Dissertation PublishingUMI Number 3702630.
Slavin, R. E. 2009. Psikologi Pendidikan Teori dan Praktik Edisi Kedelapan, Jilid 2. Jakarta Barat: Indeks.

Strickland, B.R.(ed.). 2001. The Gale Ensyclopedia of Psychology (2th ed), "Character", pp. 110-111 New York: Gale Group.

Tosti. H.T.C., Stephen. J. H. Y., \& Gwo J.H. 2014. "An Augument Reality Based Mobile Learning System to Improve Student's Learning A chievements and Motivations in Natural Science Inquiry Activities". Educational Technology \& Society,Vol. 17, pp. 352-365.

Weissbourd, R., Scherer, M., \& Alexandria, VA. 2009. "The Schools We Mean to Be, Supporting Child: Reflections on BestPracticesin Learning". E ducational Leadership, Vol.66, No. 8,pp. 231-241.

Woolfolk, A. 2009. Educational Psycology A ctive Learning Edition (10th ed). (Terjemahan Helly Prajitno Soetjipto \& Sri Mulyantini Soetjipto). Boston USA: Boston Pearson Education, Inc. 